\title{
OPTIMIZING THE COMBINATION OF OXYTOCIN MASSAGE AND HYPNOBREASTFEEDING FOR BREAST MILK PRODUCTION AMONG POST-PARTUM MOTHERS
}

\author{
Lutfiana Puspita Sari ${ }^{1}$, Harsono Salimo²), Uki Retno Budihastuti3) \\ ${ }^{1)}$ Masters Program in Public Health, Sebelas Maret University \\ 2)Department of Pediatrics, Dr. Moewardi Hospital, Surakarta \\ 3)Department of Obstetric and Gynecology, Dr. Moewardi Hospital, Surakarta
}

\begin{abstract}
Background: The incidence of post-partum blues both in Indonesia and abroad has been quite high; the stress that post-partum mothers experience will inhibit breast milk production and, as a result, breastfeeding process should be stopped earlier. Hypnobreastfeeding relaxation and oxytocin massage have been a combination of therapy that might decrease the rate of Adenocorticotropic Hormon (ACTH). This study aimed to analyze the optimization of the combination of oxytocin massage and hypnobreastfeeding in order to decrease anxiety and to improve breast milk production among post-partum mothers.
\end{abstract}

Subjects and Method: This was an analytic experimental study with Randomized Control Trial (RCT) design. This study was conducted at Dr. Suradji Tirtonegoro Central General Hospital, Klaten, from January $25^{\text {th }}, 2017$ until March $9^{\text {th }}$, 2017. The population in this study was 200 post-partum mothers. A sample of 60 post-partum mothers was selected for this study and allocated into the intervention group $(\mathrm{n} 1=30)$ and the control group (n2= 30). The intervention group would be treated by the combination of oxytocin massage and hypnobreastfeeding. The dependent variables were anxiety and breast milk production. The independent variables were oxytocin massage and hypnobreastfeeding. The anxiety was measured by STAI scale. The breast milk production process was measured by checklist questionnaire. The breast milk production amount was measured by milking cups. The breast milk production between the two groups was tested by Mann-Whitney.

Results: The anxiety scale in the intervention group was better and lower than that of the control group. The differences in terms of anxiety scale between the intervention group (median= 24.00; $\mathrm{SD}=4.45$ ) and the control group (median $=34.00 ; \mathrm{SD}=6.93$ ) were statistically significant $(\mathrm{p}<0.001)$. Then, the differences in terms of breast milk production process between the intervention group (median $=9.00 ; \mathrm{SD}=1.66$ ) and the control group (median=8.00; $\mathrm{SD}=1.56)$ were nearly significant $(\mathrm{p}<0.145)$. Furthermore, the differences in terms of breast milk production amount between the intervention group (median $=10.00 ; \mathrm{SD}=10.36$ ) and the control group (median=4.50; $\mathrm{SD}=4.21)$ were statistically significant $(\mathrm{p}<0.001)$.

Conclusion: Combination of oxytocin massage and hypnobreastfeeding can effectively decreasing anxiety and increasing breast milk production for postpartum mothers.

Keywords: oxytocin massage, hypnobreastfeeding, breast milk production, post-partum

Correspondence: Lutfiana Puspita Sari. Masters Program in Public Health, Sebelas Maret University, Jl. Ir. Sutami 36 A, Surakarta 57126, Central Java, Indonesia. Email: bidanlutfiana@gmail.com. Mobile: +6282221522374. 